\title{
Adenosine induces growth-cone turning of sensory neurons
}

\author{
Benjamin Grau • John-Christian Eilert • \\ Sebastian Munck • Hartmann Harz
}

Received: 5 June 2008 / Accepted: 4 August 2008 / Published online: 6 September 2008

(C) The Author(s) 2008. This article is published with open access at Springerlink.com

\begin{abstract}
The formation of appropriate connections between neurons and their specific targets is an essential step during development and repair of the nervous system. Growth cones are located at the leading edges of the growing neurites and respond to environmental cues in order to be guided to their final targets. Directional information can be coded by concentration gradients of substrate-bound or diffusible-guidance molecules. Here we show that concentration gradients of adenosine stimulate growth cones of sensory neurons (dorsal root ganglia) from chicken embryos to turn towards the adenosine source. This response is mediated by adenosine receptors. The subsequent signal transduction process involves cAMP. It may be speculated that the in vivo function of this response is concerned with the formation or the repair and regeneration of the peripheral nervous system.
\end{abstract}

Electronic supplementary material The online version of this article (doi:10.1007/s11302-008-9121-3) contains supplementary material, which is available to authorised users.

\section{B. Grau}

Department of Cellular, Molecular,

and Developmental Neurobiology, Cajal Institute, C.S.I.C.,

Ave. Dr. Arce 37,

Madrid 28002, Spain

J.-C. Eilert $\cdot$ H. Harz $(\bowtie)$

BioImaging Zentrum der

Ludwig-Maximilians-Universität München,

Großhaderner Straße 2,

82152 Martinsried, Germany

e-mail: harz@biz.uni-muenchen.de

S. Munck

Light Microscopy and Imaging Network (LiMoNe) VIB,

Department of Molecular and Developmental Genetics,

K.U.Leuven Campus Gasthuisberg, Herestraat 49, Box 602, 3000

Leuven, Belgium
Keywords Growth cone · Guidance · DRG · Gradient . cAMP. Adenosine receptor

\section{Introduction}

Many guidance molecules not only control the growth direction, but also affect neurite initiation and elongation [1]. Purins are interesting in this respect as it has been shown that they are capable of promoting neurite growth [2-5] and that micro-gradients of ATP induce growth-cone turning of embryonic neurons from Xenopus [6]. Here we investigate a possible involvement of adenosine in growthcone turning of neurons, a new function for this molecule. An example that adenosine may have new, so far unknown, cell biological functions has been recently given by Chen and colleagues [7], who showed that adenosine regulates migration speed of neutrophil cells during chemotaxis.

Effects of extracellular adenosine are mediated by receptors belonging to the super family of $G$ protein-coupled receptors [8], which also include members known to mediate growth-cone turning $[9,10]$. The family of adenosine receptors comprises four subtypes, $A_{1}, A_{2 A}$, $A_{2 B}$, and $A_{3}$ [11], linked to a variety of downstream signalling pathways, both cAMP dependent and independent $[12,13]$. Whereas the activation of $A_{1}$ or $A_{3}$ receptors decreases the intracellular cAMP concentration by inhibition of the adenylate cyclase, $A_{2 A}$ and $A_{2 B}$ receptor activation stimulates adenylate cyclase activity and thereby increases the intracellular cAMP concentration. It is known that cAMP has an effect on growth-cone turning [14-16], thus providing a link between adenosine receptors and growth-cone turning.

In order to induce changes in the growing direction, guidance cues must provide directional information detect- 
able by the corresponding receptors. This directional information can be coded by the shape of a concentration gradient [17]. It has been shown that concentration gradients of adenosine exist in the nervous system under in vivo conditions [18]. Due to the action of ectonucleotidases [19], each cell that releases ATP can be assumed to be the centre of an adenosine gradient. Moreover, cellular release of adenosine has also been shown [20,21].

Here we use sensory neurons from chicken dorsal root ganglia (DRG), a system that has been used by others in growth-cone-turning assays $[14,22-25]$ to investigate the effect of adenosine on growth-cone turning. We show that micro-gradients of adenosine (ADO) generated by a micropipette technique are capable of inducing a positive growthcone turning response. The present data demonstrate that the turning response is adenosine receptor mediated, as it emanates from experiments with the unspecific adenosine receptor agonist NECA and the unspecific adenosine receptor antagonist CGS 15943. Further studies with the $\mathrm{A}_{2 \mathrm{~A}}$ selective adenosine receptor agonist CGS 21680 confirm this finding and, apart from that, indicate that $\mathrm{A}_{2 \mathrm{~A}}$ receptor activation can induce a positive turning response. In contrast to this we found no effect on growth-cone turning when the $A_{1}$ receptor agonist R-(-)-PIA was used. The precise nature of the adenosine receptor(s) involved in mediating the adenosineinduced turning response will require further study. The role of cAMP during adenosine-receptor-induced growth-cone turning seems to be elusive. While the cAMP antagonist RpcAMPS or KT 5720, which is a protein kinase A (PKA) inhibitor, block growth-cone turning in ADO gradients, the turning in CGS 21680 gradients is not affected by KT 5720 , whereas Rp-cAMPS is effective and blocks CGS 21680induced turning.

\section{Materials and methods}

Cell culture and experimental procedures

Glass-bottom dishes were used for cell culture and turning experiments. To achieve optimum growth conditions, the bottom was first coated overnight with $0.1 \mathrm{mg} / \mathrm{ml}$ poly-Dlysine. Finally, the dishes were coated with $0.25 \mu \mathrm{g} / \mathrm{ml}$ laminin (Hoffmann-La Roche, Basel, Switzerland) for $1 \mathrm{~h}$ at $37^{\circ} \mathrm{C}$. DRGs were dissected from 11-day-old chicken embryos and cultivated without dissociation overnight. The cell culture medium consisted of 90\% DMEM F12 with HEPES (Invitrogen, Karlsruhe, Germany), 10\% FCS (Invitrogen, Karlsruhe, Germany), $100 \mu \mathrm{g} / \mathrm{ml}$ streptomycin, 100 units $/ \mathrm{ml}$ penicillin and was supplemented with $25 \mathrm{ng} / \mathrm{ml} 7 \mathrm{~S}$ NGF (Becton Dickinson, Franklin Lakes, NJ, USA) $[26,27]$. Mineral oil [mouse embryo tested, light oil (neat), Sigma, St. Louis, MO, USA] was used during the turning experiments to cover the cell culture medium in order to avoid outgassing and evaporation. The whole setup used to measure growth-cone turning was heated to $37^{\circ} \mathrm{C}$. Special care was taken to avoid temperature differences in the cell culture dish during the measurement to circumvent disturbance of the concentration gradients due to convection. Antagonists were added to the bath solution $30 \mathrm{~min}$ before the start of the experiment and were also present in the pipette solution.

\section{Generation of micro-gradients}

Micro-pipettes were made from borosilicate glass capillary tubes (outer diameter $1.6 \mathrm{~mm}$; wall thickness $0.336 \mathrm{~mm}$; Hilgendberg, Malsfeld, Germany) using an electrode puller (DMZ Universal Puller, Zeitz Instruments, Munich, Germany). The pulling programs were optimised to produce pipettes with either $80-100$ or $40-60 \mathrm{M} \Omega$ resistance corresponding to an inner tip diameter of 1 or $3 \mu \mathrm{m}$, respectively. All pipette solutions were filtered through a $0.2 \mu \mathrm{m}$ membrane filter to avoid clogging the pipette opening. The pipette solution was ejected by the constant hydrostatic pressure of a $35 \mathrm{~mm}$ water column. Micro-pipettes were inserted through the mineral oil layer into the cell culture dish with the help of a micro-manipulator. By rotating the cell culture dish, the angle between the pipette and longitudinal axis of the investigated neurite was adjusted to $90^{\circ}$. The pipette tip was positioned at a distance of $50 \mu \mathrm{m}$ from the growth cone and at a $45^{\circ}$ angle with respect to the direction of neurite extension.

\section{Characterisation of micro-gradients}

The shapes of the micro-gradients were characterised by using micro-pipettes that were filled with a $1 \mathrm{mM}$ solution of 5-(and-6)-carboxyfluorescein (mixed isomers). Growthcone turning is induced by concentration differences near the surface of the culture substrate where the growth cones adhere. Therefore gradients were characterised by total internal reflection fluorescence (TIRF) measurements that limit the investigated layer in the z-direction to the evanescent field depth [28]. This corresponds to the space where gradient detection by the growth cone takes place. Measurements were performed using an inverted epifluorescence microscope (Axiovert 200, Zeiss, Jena, Germany) equipped with a $100 \times$ oil immersion objective $(\alpha$ Plan Fluar $100 \times / 1.45$ oil $/ \infty / 0.17$, Zeiss, Jena, Germany), a CDD camera (IMAGO-SVGA), a TIRF condensor (TILL-TIRF module), and a $488 \mathrm{~nm}$ laser (Sapphire 488-20, Coherent, Santa Clara, CA, USA). The TIRF measurements were calibrated by normalising the background-corrected images of the gradients with an image, in which the chamber was filled with the undiluted pipette solution. 
The information on the gradient shape based on the carboxyfluorescein measurements is a reasonable estimate for the gradients in the growth-cone-turning experiments, as diffusion coefficients of carboxyfluorescein and the investigated compounds (mainly adenosine) are comparable. This is suggested by two lines of evidence. The diffusion coefficient can be calculated on the basis of the StokesEinstein radius [29], which is related to molecular weight and molecular volume. Both values are in the same range for adenosine (molecular weight: 267.24; molecular volume: $128.1 \mathrm{~cm}^{3} / \mathrm{mol}$ ) and carboxyfluoresceine (molecular weight: 332.3; molecular volume: $207.4 \mathrm{~cm}^{3} / \mathrm{mol}$ ) [30]. Further evidence comes from literature: while Rani et al. [31] give a diffusion coefficient for fluoresceine of $4.9 \times 10^{-6} \mathrm{~cm}^{2} \mathrm{~s}^{-1}$ $\left(21.5^{\circ} \mathrm{C}\right.$ in water), Mohrman [32] concludes that the diffusion coefficient of adenosine is similar to that of sucrose, which is $5.1 \times 10^{-6} \mathrm{~cm}^{2} \mathrm{~s}^{-1}$.

\section{Optical setup}

An inverted epifluorescence microscope (IX70-S1F, Olympus, Tokyo, Japan) equipped with a $40 \times$ oil immersion objective (UAPO 40× OL/340/1.35, Olympus, Tokyo, Japan) was used throughout the study except for the TIRF measurements. The setup was equipped with a CCD camera (IMAGOVGA) for time-lapse microscopy and was controlled by TILLvisIon (version 4.0), which was also used for image analysis. All imaging equipment was supplied by TILL Photonics (Gräfelfing, Germany) unless otherwise noted.

Measurement of extension and turning of growth cones

Neurite growth was analysed according to Ming et al. [33] including the modifications of Munck et al. [14]. In short, the growth direction before the onset of the stimulus was aligned with the $y$-axis of a coordinate system. Turning angles were determined by measuring the angles between the ordinate and a straight line connecting the origin of the coordinate system (starting point of the growth cone) with the final growth-cone position. Positive angles were defined to be on the right side of the ordinate (stimulated side) and negative angles to be on the left side. Data were statistically analysed using the Mann-Whitney U test. Deviations are given as standard error of the mean (SEM). All growthcone-turning experiments lasted $15 \mathrm{~min}$. Neurites that retracted during this period were not included in further analysis.

\section{Chemicals}

The following chemicals were used in growth-cone-turning assays: ADO, NECA, CGS 21680, CGS 15943, R-(-)-PIA, KT 5720 (Calbiochem-Novabiochem, San Diego, CA,
USA), and Rp-cAMPS (Biomol, Hamburg, Germany). Stock solutions of these chemicals were prepared in dimethyl sulfoxide (DMSO), with the exception of the water soluble Rp-cAMPS. If not stated otherwise, chemicals were bought from Sigma (St. Louis, MO, USA).

\section{Results}

Cultures of DRG sensory neurons from embryonic chickens have been used by various groups to investigate different aspects of growth-cone turning [14, 22-25, 34, 35]. Herein explant cultures of chicken (E 11) DRGs were used to investigate a possible effect of ADO on the direction of growth-cone advance. During time-lapse image recordings of elongating neurites, the growth cones were exposed to extracellular gradients of ADO and related compounds. The effect of these concentration gradients on growth direction was analysed on the basis of growth tracks that were extracted by image analysis from the images of the timelapse recordings (cf. "Materials and methods").

\section{Generation and characterisation of micro-gradients}

Constraints for effective guidance with soluble compounds are that the concentration falls between certain maximum and minimum limits, and that the percentage change in concentration across the width of the growth cone exceeds a certain minimum value [36]. Therefore, we characterised the pipettes and the respective gradients produced with it. Here extracellular concentration gradients were generated by gravity-driven flow of the respective compound (or vehicle control) from a micro-pipette. Two pipette types were compared, as the gradient shape and gradient evolution depend on the geometry of the pipette. The inner tip diameter was analysed with raster electron microscopy and for the small pipette type was typically $1 \mu \mathrm{m}$ and for the larger type $3 \mu \mathrm{m}$ (Fig. 1). The gradients generated with these pipettes were investigated by TIRF-microscopic measurements as described in "Materials and methods". These experiments show that the gradients stabilise within 5 min and stay stable for the duration of the experiments, and that the gradient properties depend on pipette geometry.

Using the small pipette filled with a $1 \mathrm{mM}$ solution of carboxyfluorescein, the dye concentration decreased from about $1 \mu \mathrm{M}$ at a distance of $5 \mu \mathrm{m}$ to $0.6 \mu \mathrm{M}$ at a point $50 \mu \mathrm{m}$ distant from the pipette. The corresponding data for the large pipette were $17 \mu \mathrm{M}$ at $5 \mu \mathrm{m}$ to $1.5 \mu \mathrm{M}$ at $50 \mu \mathrm{m}$ (Fig. 1). Similar diffusion coefficients of carboxyfluorescein and ADO allowed the estimation of the ADO concentrations at different distances from the pipette tip on the basis of the carboxyfluorescein data. These estimations resulted in $\mathrm{ADO}$ concentrations of $100 \mathrm{nM}$ at a 

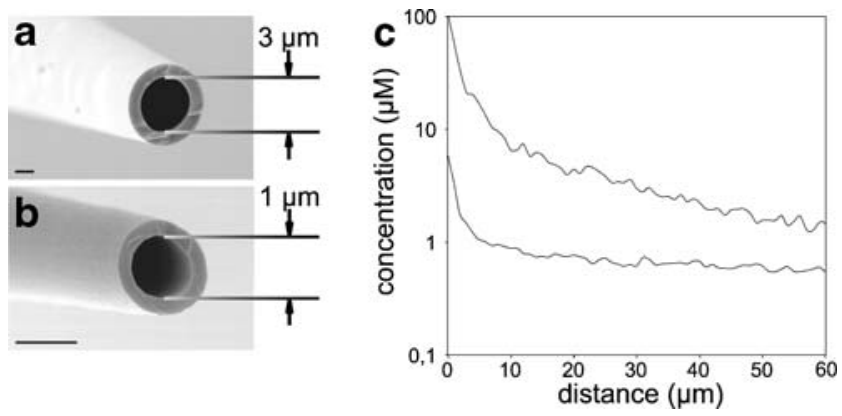

Fig. 1a-c Relation between pipette geometry and gradient shape. a, b Scanning electron microscopic images of the two compared pipette types. Scale bar in a and $\mathbf{b} 1 \mu \mathrm{m}$. c Line plot of the concentration gradients generated by the respective pipette type (upper line $3 \mu \mathrm{m}$ pipette, lower line $1 \mu \mathrm{m}$ pipette). The plot was extracted from images of a TIRF measurement, as described in the "Materials and methods" section. Measuring parameters were as follows: pipette solution: $1 \mathrm{mM}$ carboxyfluorescein; pressure: $35 \mathrm{~mm}$ water column; time: 5 min after inserting the pipette

distance of $5 \mu \mathrm{m}$ and $60 \mathrm{nM}$ at a distance of $50 \mu \mathrm{m}$ from the pipette tip for small pipettes filled with $100 \mu \mathrm{M}$ ADO. For the large pipette, the values at the corresponding positions and pipette solution were $1.7 \mu \mathrm{M}$ and $150 \mathrm{nM}$. Possible ADO content of the cell culture medium is not included in those values.

\section{Growth-cone turning in ADO gradients}

In standard experiments, the distance between growth cone and pipette tip was $50 \mu \mathrm{m}$ at the start. Neurites from control cells elongated at a mean speed of $76 \pm 5.2 \mu \mathrm{m} / \mathrm{h}(\mathrm{SEM})$. With respect to these constraints, we limited the measuring period to $15 \mathrm{~min}$ to guarantee a minimum distance between growth cone and pipette tip throughout the experiment. The turning behaviour of populations of growth cones in the presence of micro-gradients of ADO or vehicle controls is shown in Fig. 2 by superimposing traces of individual trajectories of neurite extension. A 1- $\mu \mathrm{m}$ pipette filled with $100 \mu \mathrm{M}$ ADO consistently induced a chemotrophic turning response toward the pipette over the investigated time period of $15 \mathrm{~min}$. Statistical analysis revealed that this ADO-induced turning response is significant compared to a vehicle control. Contrary to this finding, we did not observe a significant turning response using a $3-\mu \mathrm{m}$ pipette filled with $100 \mu \mathrm{M}$ ADO (Fig. 2). This result can be explained by the fact that growth-cone turning happens only if the gradient shape satisfies certain cellular conditions [36].

To examine whether growth-cone attraction by an ADO source is mediated by adenosine receptors, the unspecific adenosine receptor agonist NECA [11] was used. This agonist has a higher affinity to the different ADO receptors than ADO itself $[37,38]$. Therefore we reduced the pipette concentration of NECA by a factor of ten relative to the $\mathrm{ADO}$ concentration. The rationale behind this approach is that growth cones can detect a concentration gradient only if the respective receptors are not saturated with the ligand [17]. This experiment resulted in a significant turning of growth cones towards the pipette filled with $10 \mu \mathrm{M}$ NECA. Data are shown together with the results of other ADO receptor agonists and antagonists in Fig. 3. The turning response towards a pipette filled with $100 \mu \mathrm{M}$ ADO could be blocked by using the unspecific ADO receptor antagonist CGS 15943 [39]. This antagonist was added both to the bath solution and to the pipette solution in a concentration of $10 \mu \mathrm{M}$.

The experiments with unspecific ADO receptor agonists and antagonists indicated that the ADO-induced growthcone turning is transduced by $\mathrm{ADO}$ receptors. As the $\mathrm{A}_{2 \mathrm{~B}}$ and the $\mathrm{A}_{3}$ receptors have only a low affinity to $\mathrm{ADO}\left(\mathrm{K}_{\mathrm{D}}\right.$ 5,100 and $6,500 \mathrm{nM}$ respectively [38]), a significant participation of these receptors in growth-cone-turning experiments seems implausible as the ADO concentration in this experiments was less than $100 \mathrm{nM}$. From this point of view the $A_{1}$ and $A_{2 A}$ receptors seem to be better candidates, as the binding constants of these receptors are $70 \mathrm{nM}\left(\mathrm{A}_{1}\right)$ and $150 \mathrm{nM}\left(\mathrm{A}_{2 \mathrm{~A}}\right)$ [38].

Therefore, we tested the effect of R-(-)-PIA, an $A_{1}$ receptor specific agonist [37]. Addition of $2 \mu \mathrm{M}$ to the pipette solution was ineffective in inducing growth-cone
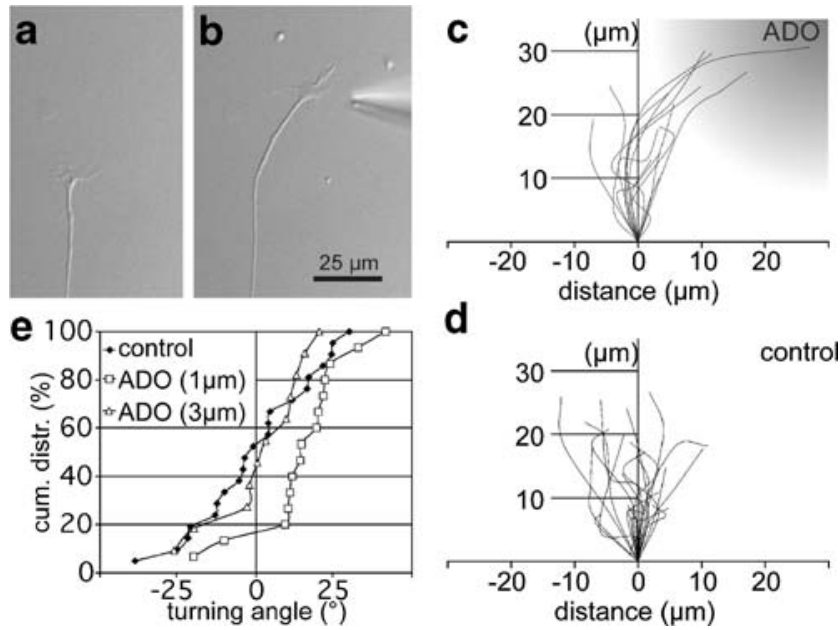

Fig. 2a-e Adenosine induces positive turning of growth cones. Image of a growth cone from a chick sensory neuron $\mathbf{a}$ before and $\mathbf{b} 15 \mathrm{~min}$ after insertion of a $1-\mu \mathrm{m}$ pipette filled with $100 \mu \mathrm{M}$ ADO. c, d Trajectories of neurites grown for $15 \mathrm{~min}$ in a gradient. The pipette solution contained either c $100 \mu \mathrm{M}$ ADO or d $10 \mu \mathrm{l} / \mathrm{ml}$ DMSO for the control. The trajectories were aligned in such a way that growth cones started from the origin and grew in direction of the ordinate. The ADO gradient is visualised schematically. e Cumulative distribution of turning angles of the growth cones exposed to gradients produced by a $1-\mu \mathrm{m}$ pipette filled with either control solution (diamonds) or $100 \mu \mathrm{M}$ $\mathrm{ADO}$ (squares) and a $3-\mu \mathrm{m}$ pipette filled with $100 \mu \mathrm{M}$ ADO (triangles). Values at the ordinate refer to the percentage of neurites with a turning angle inferior or equal to the angle given at the abscissa. Under experimental conditions which induce growth-cone attraction, the curve is shifted to the right 


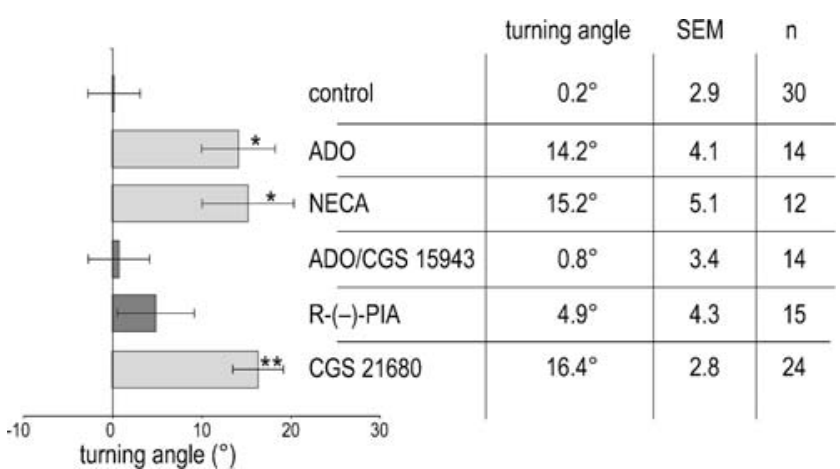

Fig. 3 Effects of different adenosine receptor agonists and antagonists on growth-cone turning. All experiments were performed with $1-\mu \mathrm{m}$ pipettes filled with the respective agonist or $10 \mu \mathrm{l} / \mathrm{ml}$ DMSO for the control. Both ADO $(100 \mu \mathrm{M})$ and the unspecific adenosine receptor agonist NECA $(10 \mu \mathrm{M})$ induced a significant positive turning response. In the presence of the unspecific adenosine receptor antagonist CGS 15943, no ADO-induced turning response was detectable. CGS 15943 was added to the culture medium and to the pipette solution in a concentration of $10 \mu \mathrm{M}$. The $A_{1}$ receptor specific agonist R-(-)-PIA $(10 \mu \mathrm{M})$ caused no significant turning response. In contrast to this, a positive turning response was induced by the specific $\mathrm{A}_{2 \mathrm{~A}}$ receptor agonist CGS $21680(10 \mu \mathrm{M})$. Displayed are the average turning angles, error bars indicate standard error of the mean (SEM), and $n$ the sample size. Significant differences from the control group are marked ( $* P<0.05 ; * * P<0.01$; Mann-Whitney U test)

turning (data not shown). As the absence of a turning response can always be caused by inappropriate gradient shape, we tested whether a concentration increase to $10 \mu \mathrm{M}$ in the stimulating pipette has any effect (Fig. 3). However, this condition was as ineffective as a decreased start distance $(35 \mu \mathrm{m}$ instead of $50 \mu \mathrm{m})$ between growth cone and a micro-pipette containing $2 \mu \mathrm{M}$ R-(-)-PIA (data not shown). In summary, we have no indication that a growthcone turning response can be activated by R-(-)-PIA. In contrast to this, a pipette filled with $10 \mu \mathrm{M}$ of the $\mathrm{A}_{2 \mathrm{~A}}$ receptor specific agonist CGS 21680 [40] induced a significant attractant response.

These results provide additional evidence that the observed turning response is mediated by adenosine receptors. Moreover, the results suggest that $\mathrm{A}_{2 \mathrm{~A}}$ receptor activation is involved in adenosine-induced growth-cone turning of chicken sensory neurons.

First investigations on the signal transduction chain of ADO-induced growth-cone turning

It is well known that cAMP is an important downstream signal transducer of adenosine receptors [13]. Therefore, we tested the effect of the cAMP antagonist Rp-cAMPS [41] on adenosine-induced growth-cone turning. This membrane permeable antagonist was added in a concentration of $20 \mu \mathrm{M}$ (data not shown) or $100 \mu \mathrm{M}$ to the bath and pipette solution. Under these conditions the attractant response towards a pipette that contained $100 \mu \mathrm{M}$ of $\mathrm{ADO}$, in addition to the antagonist, was inhibited. Rp-cAMPS also blocked the attractant response towards a pipette filled with the specific $\mathrm{A}_{2 \mathrm{~A}}$ receptor agonist CGS 21680. In these experiments, the pipette contained $10 \mu \mathrm{M}$ CGS 21680 and Rp-cAMPS was added to the bath and to the pipette solution in a concentration of $100 \mu \mathrm{M}$. Together these data suggest a contribution of cAMP to the signal transduction chain of adenosine-receptor-induced growth-cone turning (Fig. 4).

Different downstream effectors of cAMP are known [42]. One important member of this group is PKA, which can be blocked by the specific inhibitor KT 5720 [43]. Here we tested the effect of KT 5720 on adenosine-receptormediated growth-cone turning. KT 5720 was added to bath and pipette solution in a concentration of $10 \mu \mathrm{M}$. Under these experimental conditions growth-cone turning towards a pipette that contained $100 \mu \mathrm{M}$ of ADO was blocked significantly. However, under the same experimental conditions, KT 5720 failed to block the attractant response of a pipette filled with $10 \mu \mathrm{M}$ of the $\mathrm{A}_{2 \mathrm{~A}}$ specific agonist CGS 21680 (Fig. 4). These seemingly inconsistent results reveal the need for a thorough investigation of the signal transduction chain.

\section{Discussion}

The present study demonstrates, for the first time, that extracellular ADO gradients can guide neuronal processes.

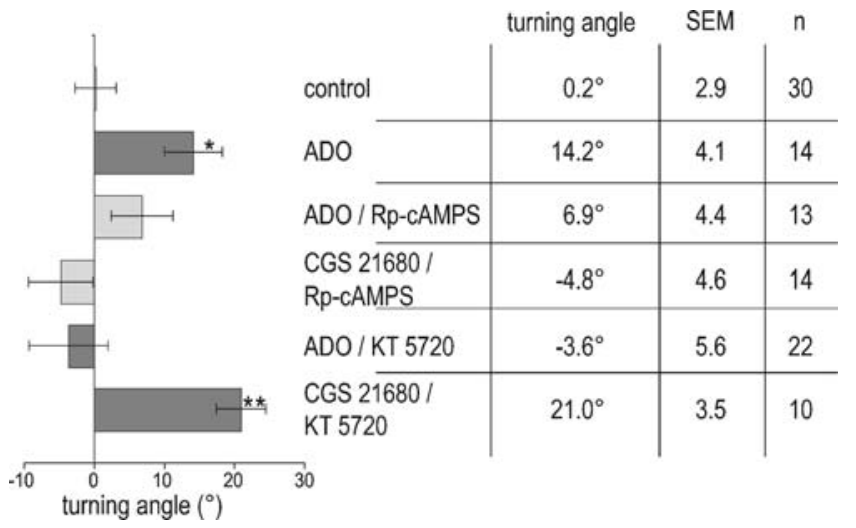

Fig. 4 Effect of cAMP signalling on adenosine-receptor-mediated growth-cone turning. The cAMP antagonist Rp-cAMPS $(100 \mu \mathrm{M})$ inhibits growth-cone turning induced by a $1-\mu \mathrm{m}$ pipette filled with ADO $(100 \mu \mathrm{M})$ or CGS $21680(10 \mu \mathrm{M})$. Whereas the PKA inhibitor KT $5720(10 \mu \mathrm{M})$ blocked the turning of growth cones in an ADO gradient, this was not the case when the $\mathrm{A}_{2 \mathrm{~A}}$ receptor selective agonist CGS 21680 was used as a chemoattractant. Displayed are the average turning angles, error bars indicate standard error of the mean (SEM), and $n$ the sample size. Significant differences from the control group are marked $(* P<0.05 ; * * P<0.01$; Mann-Whitney U test). Antagonists and inhibitors were added to the culture medium and pipette solution. Data of the control experiments and the ADO-induced turning have been taken from Fig. 3 
Experiments with adenosine receptor agonists and antagonists strongly indicate that the turning reaction is caused by activation of adenosine receptors. Adenosine receptors belong to the large family of seven transmembrane $G$ protein-coupled receptors [8], which contain members known to be involved in growth-cone turning $[9,10]$.

The finding that micro-gradients of ADO induce growthcone turning is unexpected because of negative results in comparable experiments $[6,44]$. This apparent discrepancy with our results may be explained by experimental differences. First of all, the data published so far are derived from spinal neurons of Xenopus, whereas we investigated sensory neurons from chicken. Another difference is the concentration of the agonists used in the studies mentioned above. Fu and colleagues [6] used a pipette solution containing a 30fold higher concentration of ADO than in the present study, and Stein et al. [44] performed the experiments with a 100fold higher concentration of NECA compared to the concentration in this work. Even though it is hard to compare micro-gradients used by different labs just on the basis of published data, we estimate that the agonist concentrations used in the former studies were significantly higher than those used in this work, not only in the pipette solution but also at the site of the growth cones. Our finding that micro-gradients produced by micro-pipettes with an increased tip diameter did not attract growth cones supports the interpretation that high concentrations counteract the attractive effect of ADO. It is known from the work of Goodhill [17] that gradient detection is disturbed if the agonist concentration is high compared to the dissociation constant for the receptor-ligand complex. In this case almost all receptors are bound, hence yielding little difference in binding across the extent of the growth cone. Another reason for the ineffectiveness of high ADO concentrations might be that in case of adenosine receptors, one cell can express several receptor subtypes with different binding constants and diverse physiological effects. Therefore, at high ADO concentrations the summed response of different adenosine receptor subtypes may not favour growth-cone turning.

Homologues to all four known human ADO receptors have been found in the chicken genome [45-48]. It has been shown that $A_{1}$ and $A_{2 A}$ receptors are present at sensory neurons of rodents $[49,50]$. We are not aware of published data showing the presence of ADO receptors on chicken sensory neurons, but all experiments with agonists and antagonists shown here indicate that ADO receptors are present on growth cones of chicken sensory neurons and are responsible for the observed growth-cone turning response. The affinities of the different adenosine receptor subtypes range from an adenosine concentration of $\sim 70 \mathrm{nM}$ for the $\mathrm{A}_{1}$ receptor up to $\sim 6,500 \mathrm{nM}$ for the $\mathrm{A}_{3}$ receptor subtype $[38,51]$. Here we show that micro-gradients effective in growth-cone turning have an adenosine con- centration between 60 and $100 \mathrm{nM}$. Consequently, the best candidates for mediating the adenosine response shown here are the high affinity receptors, namely the $\mathrm{A}_{1}$ $(\sim 70 \mathrm{nM})$ and the $\mathrm{A}_{2 \mathrm{~A}}(\sim 150 \mathrm{nM})$ receptor. Experiments with the subtype-specific adenosine receptor agonist CGS 21680 [40] indicate a function of the $\mathrm{A}_{2 \mathrm{~A}}$ receptor in adenosine-induced growth-cone turning, whereas no response was detectable with the usage of the $A_{1}$ receptor specific agonist R-(-)-PIA [37]. The latter result argues against a major contribution of the $A_{1}$ receptor in the observed turning response. However, remarkable species differences have been observed for adenosine receptor agonists [37], and chicken adenosine receptors are pharmacologically not well characterised. Therefore future experiments with ADO receptor subtype-specific ligands have to clarify whether $\mathrm{A}_{2 \mathrm{~A}}$ receptor activation is necessary or sufficient to induce growth-cone turning in sensory neurons. In particular antagonists (e.g. SCH 58261 [52]) seem interesting due to the fact that they remove a single player from the set of different adenosine receptor subtypes that could be present on the growth cone.

ADO receptor signalling is classically thought to occur through changing the intracellular cAMP level [53]. Indeed the presented results show that the cAMP antagonist RpcAMPS blocks growth-cone turning induced by ADO or the $\mathrm{A}_{2 \mathrm{~A}}$ specific agonist CGS 21680. However no clear picture has emerged by testing a possible involvement of PKA, an important downstream effector of cAMP. The PKA-specific inhibitor KT 5720 [43] has different effects, depending on the used chemoattractant. KT 5720 blocks the attractant effect of ADO, but not of CGS 21680. One explanation for this phenomenon could be that ADO and CGS 21680 activate different subsets of the four known ADO receptors. As ADO receptors couple to an intricate network of signalling pathways [54], the activation of different receptor subsets could be the reason for the observed difference in sensitivity to KT 5720. Off-target effects of CGS 21680 to proteins other than ADO receptors could be an alternative explanation and show the need for future thorough pharmaceutical characterisation of the signal transduction chain.

Besides PKA as a target of cAMP, the importance of 'exchange protein activated by cyclic AMP' (EPAC) has also become generally known [55]. It has been shown that activation of EPAC can promote neurite extension in PC12 cells and that EPAC acts in synergy with PKA during this process [56]. On this basis one might speculate that EPAC could also be involved in ADO-induced growth-cone turning. Our finding that cAMP participates - at least to some extent - in the signal transduction chain of ADOinduced growth-cone turning is not unexpected, as examples of cAMP-dependent growth-cone turning have been published $[10,14]$. On the other hand, a contribution of 
cAMP-independent mechanisms cannot be excluded on the basis of the current data.

The present results show that concentration gradients of $\mathrm{ADO}$ can induce changes in the growth direction of neurons, raising the question of sources and sinks of extracellular ADO. Extracellular ADO is either released from cells via transporters or generated from extracellular adenine nucleotides by the action of ectonucleotidases [19-21]. Not only ADO sources, but also the mechanisms for removal of ADO from the extracellular space are diverse and widely distributed $[20,38]$. Therefore, it can be assumed that ADO concentration gradients that evolve between ADO sources and sinks are widespread. Direct measurements of such gradients are rare, but in a report of Chuna [18], evidence has been provided for an ADO concentration gradient that surrounds electrically stimulated hippocampal neurons.

At the moment only in vitro data on ADO-induced growth-cone turning are available, so one can only speculate on the physiological role and significance of the observed effect. However, as ADO is known to have significant effects in wound healing [57], it might also support the reinervation of tissue with sensory neurons after lesions.

Acknowledgements We thank G. Wanner and E. Facher for scanning electron microscopic analysis of the pipettes, E. Bartl for her work during the initial phase of the project, TILL Photonics (now part of Agilent Technologies) for assistance with TIRF microscopy, and Dave Vogel for his valuable comments on the text. This work was funded by grants from the Bundesministerium für Bildung und Forschung within the 'Biophotonik' programme (FKZ 13N8780 and FKZ 13N9267).

Open Access This article is distributed under the terms of the Creative Commons Attribution Noncommercial License which permits any noncommercial use, distribution, and reproduction in any medium, provided the original author(s) and source are credited.

\section{References}

1. Goldberg JL (2003) How does an axon grow? Genes Dev 17:941958. doi:10.1101/gad.1062303

2. Höpker VH, Saffrey MJ, Burnstock G (1996) Neurite outgrowth of striatal neurons in vitro: involvement of purines in the growthpromoting effect of myenteric plexus explants. Int J Dev Neurosci $14: 439-451$

3. Schäfer KH, Saffrey MJ, Burnstock G (1995) Trophic actions of 2-chloroadenosine and bFGF on cultured myenteric neurones. Neuroreport 6:937-941

4. Rathbone MP, Middlemiss PJ, Gysbers JW et al (1999) Trophic effects of purines in neurons and glial cells. Prog Neurobiol 59:663-690. doi:10.1016/S0301-0082(99)00017-9

5. Zimmermann H (2006) Nucleotide signaling in nervous system development. Pflugers Arch 452:573-588. doi:10.1007/s00424006-0067-4

6. Fu WM, Tang YB, Lee KF (1997) Turning of nerve growth cones induced by the activation of protein kinase C. Neuroreport 8:2005-2009
7. Chen Y, Corriden R, Inoue $\mathrm{Y}$ et al (2006) ATP release guides neutrophil chemotaxis via P2Y2 and A3 receptors. Science 314:1792-1795. doi:10.1126/science.1132559

8. Horn F, Vriend G, Cohen FE (2001) Collecting and harvesting biological data: the GPCRDB and NucleaRDB information systems. Nucleic Acids Res 29:346-349. doi:10.1093/nar/29.1.346

9. Xiang Y, Li Y, Zhang Z et al (2002) Nerve growth cone guidance mediated by $G$ protein-coupled receptors. Nat Neurosci 5:843848. doi:10.1038/nn899

10. Guirland C, Buck KB, Gibney JA et al (2003) Direct cAMP signaling through G-protein-coupled receptors mediates growth cone attraction induced by pituitary adenylate cyclase-activating polypeptide. J Neurosci 23:2274-2283

11. Fredholm BB, Ijzerman AP, Jacobson KA et al (2001) International Union of Pharmacology. XXV. Nomenclature and classification of adenosine receptors. Pharmacol Rev 53:527-552

12. Cunha RA (2001) Adenosine as a neuromodulator and as a homeostatic regulator in the nervous system: different roles, different sources and different receptors. Neurochem Int 38:107125. doi:10.1016/S0197-0186(00)00034-6

13. Ralevic V, Burnstock G (1998) Receptors for purines and pyrimidines. Pharmacol Rev 50:413-492

14. Munck S, Bedner P, Bottaro T et al (2004) Spatiotemporal properties of cytoplasmic cyclic AMP gradients can alter the turning behaviour of neuronal growth cones. Eur J Neurosci 19:791-797. doi:10.1111/j.0953-816X.2004.03118.x

15. Lohof AM, Quillan M, Dan Y et al (1992) Asymmetric modulation of cytosolic cAMP activity induces growth cone turning. J Neurosci 12:1253-1261

16. Song HJ, Poo MM (2001) The cell biology of neuronal navigation. Nat Cell Biol 3:E81-E88. doi:10.1038/35060164

17. Goodhill GJ (1998) Mathematical guidance for axons. Trends Neurosci 21:226-231. doi:10.1016/S0166-2236(97)01203-4

18. Cunha RA (1997) Release of ATP and adenosine and formation of extracellular adenosine in the hippocampus. In: Okada Y (ed) The role of adenosine in the nervous system. Elsevier, Amsterdam, pp $135-142$

19. Zimmermann H (2000) Extracellular metabolism of ATP and other nucleotides. Naunyn Schmiedebergs Arch Pharmacol 362:299-309. doi:10.1007/s002100000309

20. King AE, Ackley MA, Cass CE et al (2006) Nucleoside transporters: from scavengers to novel therapeutic targets. Trends Pharmacol Sci 27:416-425. doi:10.1016/j.tips.2006.06.004

21. Schwiebert EM, Zsembery A, Geibel JP (2003) Cellular mechanisms and physiology of nucleotide and nucleoside release from cells: current knowledge, novel assays to detect purinergic agonists, and future directions. In: Schwiebert EM (ed) Extracellular nucleotides and nucleosides: release, receptors, and physiological and pathophysiological effects. Academic Press, Amsterdam, pp 31-58

22. Gallo G, Lefcort FB, Letourneau PC (1997) The trkA receptor mediates growth cone turning toward a localised source of nerve growth factor. J Neurosci 17:5445-5454

23. Adams DN, Kao EY, Hypolite CL et al (2005) Growth cones turn and migrate up an immobilized gradient of the laminin IKVAV peptide. J Neurobiol 62:134-147. doi:10.1002/neu.20075

24. Cao X, Shoichet MS (2003) Investigating the synergistic effect of combined neurotrophic factor concentration gradients to guide axonal growth. Neuroscience 122:381-389. doi:10.1016/ j.neuroscience.2003.08.018

25. Dontchev VD, Letourneau PC (2003) Growth cones integrate signaling from multiple guidance cues. J Histochem Cytochem 51:435-444

26. Nishi R (1996) Autonomic and sensory neuron cultures. In: Bronner-Fraser M (ed) Methods in cell biology, methods in avian embryology, vol 51. Academic Press, San Diego, pp 249-263 
27. Smith CL (1998) Cultures from chick periperal ganglia. In: Banker G, Goslin K (eds) Culturing nerve cells. MIT Press, Cambridge, pp 261-287

28. Axelrod D, Burghardt TP, Thompson NL (1984) Total internal reflection fluorescence. Annu Rev Biophys Bioeng 13:247-268. doi:10.1146/annurev.bb.13.060184.001335

29. Einstein A (1956) Investigations on the theory of the Brownian movement. Dover, New York

30. CAS (2008) SciFinder scholar. http://www.cas.org/SCIFINDER/ SCHOLAR/. Accessed 16 Jan 2008

31. Rani SA, Pitts B, Stewart PS (2005) Rapid diffusion of fluorescent tracers into Staphylococcus epidermidis biofilms visualized by time lapse microscopy. Antimicrob Agents Chemother 49:728732. doi:10.1128/AAC.49.2.728-732.2005

32. Mohrman DE (1988) Adenosine handling in interstitia of cremaster muscle studied by bioassay. Am J Physiol 254:H369-H376

33. Ming GL, Song HJ, Berninger B et al (1997) cAMP-dependent growth cone guidance by netrin-1. Neuron 19:1225-1235. doi:10.1016/S0896-6273(00)80414-6

34. Gundersen RW, Barrett JN (1979) Neuronal chemotaxis: chick dorsal-root axons turn toward high concentrations of nerve growth factor. Science 206:1079-1080. doi:10.1126/science.493992

35. Gundersen RW, Barrett JN (1980) Characterization of the turning response of dorsal root neurites toward nerve growth factor. J Cell Biol 87:546-554. doi:10.1083/jcb.87.3.546

36. Goodhill GJ (1997) Diffusion in axon guidance. Eur J Neurosci 9:1414-1421. doi:10.1111/j.1460-9568.1997.tb01496.x

37. Klotz KN (2000) Adenosine receptors and their ligands. Naunyn Schmiedebergs Arch Pharmacol 362:382-391. doi:10.1007/ s002100000315

38. Dunwiddie TV, Masino SA (2001) The role and regulation of adenosine in the central nervous system. Annu Rev Neurosci 24:31-55. doi:10.1146/annurev.neuro.24.1.31

39. Ongini E, Dionisotti S, Gessi S et al (1999) Comparison of CGS 15943, ZM 241385 and SCH 58261 as antagonists at human adenosine receptors. Naunyn Schmiedebergs Arch Pharmacol 359:7-10. doi:10.1007/PL00005326

40. Jarvis MF, Schulz R, Hutchison AJ et al (1989) [3H]CGS 21680, a selective A2 adenosine receptor agonist directly labels A2 receptors in rat brain. J Pharmacol Exp Ther 251:888-893

41. Rothermel JD, Parker Botelho LH (1988) A mechanistic and kinetic analysis of the interactions of the diastereoisomers of adenosine $3^{\prime}, 5^{\prime}$-(cyclic)phosphorothioate with purified cyclic AMP-dependent protein kinase. Biochem J 251:757-762

42. Kopperud R, Krakstad C, Selheim F et al (2003) cAMP effector mechanisms. Novel twists for an 'old' signaling system. FEBS Lett 546:121-126. doi:10.1016/S0014-5793(03)00563-5

43. Kase H, Iwahashi K, Nakanishi S et al (1987) K-252 compounds, novel and potent inhibitors of protein kinase $\mathrm{C}$ and cyclic nucleotide-dependent protein kinases. Biochem Biophys Res Commun 142:436-440. doi:10.1016/0006-291X(87)90293-2

44. Stein E, Zou Y, Poo MM et al (2001) Binding of DCC by netrin1 to mediate axon guidance independent of adenosine A2B receptor activation. Science 291:1976-1982. doi:10.1126/science. 1059391

45. International Chicken Genome Sequencing Consortium (2004) Sequence and comparative analysis of the chicken genome provide unique perspectives on vertebrate evolutio. Nature 432:695-716

46. Aguilar JS, Tan F, Durand I et al (1995) Isolation and characterization of an avian A1 adenosine receptor gene and a related cDNA clone. Biochem J 307(Pt 3):729-734

47. Durand ICH, Green RD (2001) Cloning of a chick A3 adenosine receptor: characterization of ligand binding and receptor-effector coupling of chick A1 and A3 adenosine receptors. Naunyn Schmiedebergs Arch Pharmacol 363:81-86. doi:10.1007/s00210 0000340

48. Worpenberg S, Burk O, Klempnauer KH (1997) The chicken adenosine receptor $2 \mathrm{~B}$ gen eis regulated by $\mathrm{v}-\mathrm{myb}$. Oncogene 15:213-221. doi:10.1038/sj.onc.1201179

49. Kaelin-Lang A, Lauterburg T, Burgunder JM (1998) Expression of denosine A2a receptor gene in a dorsal root and autonomic ganglia. Neurosci Lett 246:21-24. doi:10.1016/S0304-3940(98) 00216-X

50. Sawynok J (1998) Adenosine receptor activation and nociception. Eur J Pharmacol 347:1-11. doi:10.1016/S0014-2999(97) 01605-1

51. Yaar R, Jones MR, Chen JF et al (2005) Animal models for the study of adenosine receptor function. J Cell Physiol 202:9-20. doi:10.1002/jcp. 20138

52. Zocchi C, Ongini E, Conti A et al (1996) The non-xanthine heterocyclic compound SCH 58261 is a new potent and selective A2a adenosine receptor antagonist. J Pharmacol Exp Ther 276: 398-404

53. Jacobson KA, Gao ZG (2006) Adenosine receptors as therapeutic targets. Nat Rev Drug Discov 5:247-264. doi:10.1038/nrd1983

54. Schulte G, Fredholm BB (2003) Signalling from adenosine receptors to mitogen-activated protein kinases. Cell Signal 15:813-827. doi:10.1016/S0898-6568(03)00058-5

55. Bos JL (2003) Epac: a new cAMP target and new avenues in cAMP research. Nat Rev Mol Cell Biol 4:733-738. doi:10.1038/nrm1197

56. Christensen AE, Selheim F, de Rooij J et al (2003) cAMP analog mapping of Epac1 and cAMP kinase. Discriminating analogs demonstrate that Epac and cAMP kinase act synergistically to promote PC-12 cell neurite extension. J Biol Chem 278:35394 35402. doi:10.1074/jbc.M302179200

57. Cronstein BM (2006) Adenosine receptors and wound healing, revised. Sci World J 6:984-991. doi:10.1100/tsw.2006.194 